\title{
DETERMINATION OF THE PROBABILITY FACTOR OF PARTICLES MOVEMENT IN A GAS-DISPERSED TURBULENT FLOW
}

\author{
Saltanat Adikanova ${ }^{1}$, Waldemar Wójcik ${ }^{2}$, Natalya Denissova ${ }^{3}$, Yerzhan Malgazhdarov ${ }^{3}$, \\ Ainagul Kadyrova ${ }^{1}$ \\ ${ }^{1}$ S. Amanzholov East Kazakhstan State University, Ust-Kamenogorsk, Kazakhstan, ${ }^{2}$ Lublin University of Technology, Lublin, Poland, ${ }^{3}$ D. Serikbayev East Kazakhstan State \\ Technical University, Ust-Kamenogorsk, Kazakhstan
}

Abstract. The goal of the work is to define the probability factor of particles movement in a gas-dispersed turbulent flow. The object of the research is the description of harmful impurities transfer process in the atmosphere with the help of mathematical modelling of variability of gas and aerosol composition of atmosphere. Another object is assessment atmospheric impurities on the environment. The novelty of the research is that probabilitystatistical approach is used in modelling the transfer of harmful impurities from anthropogenic sources into the atmosphere.

Keywords: probability factor of particles movement, transfer of harmful impurities, environment, anthropogenic sources, pollutions, information system.

\section{WYZNACZENIE WSPÓŁCZYNNIKA PRAWDOPODOBIEŃSTWA RUCHU CZĄSTEK STALYCH W TURBULENTNYM PRZEPLYWIE DYSPERSYJNYM W FAZIE GAZOWEJ}

Streszczenie. Celem pracy jest określenie wspótczynnika prawdopodobieństwa ruchu cząstek w przepływie turbulentnym dyspersyjnym $w$ gazie. Celem pracy jest opisanie procesu przenoszenia szkodliwych zanieczyszczeń do atmosfery za pomoca matematycznego modelowania zmienności składu gazów i aerozoli atmosferycznych oraz ocena wplywu zanieczyszczeń atmosferycznych na środowisko. Nowościa tych badań jest zastosowanie probabilistycznego i statystycznego podejścia do modelowania transferu szkodliwych zanieczyszczeń ze źródel antropogenicznych do atmosfery.

Słowa kluczowe: współczynnik prawdopodobieństwa ruchu cząstek, transfer szkodliwych zanieczyszczeń, środowisko, źródła antropogeniczne, zanieczyszczenia, system informacyjny

\section{Introduction}

Anthropogenic sources of pollution influence the environment and affects the state of air basin. The problems of air basin protection are included in a wide research area on the junction of several sciences. Pollution of atmosphere surface layer is the most relevant problem nowadays.

The pattern of flow and dissemination of harmful substances and their compounds that locally contaminate air surface layer considerably differs from these phenomena in fee atmosphere. The solution of scientific and applied problems of environment protection requires detailed description of processes of harmful substances dissemination in air basin of industrial regions. Recently, these problems have become urgent especially in large industrial cities due to the activities of big industrial enterprises.

Experimental researches in this sphere are connected with significant investments and hampered due to large spatial scale of the process. Besides, the experiment enables to build up situation forecast in case of atmospheric conditions change (speed and direction of wind, atmospheric pressure) Mathematical modeling in this direction enables to track and forecast impurities dissemination in atmosphere surface layer taking into account real conditions of a region and change of meteorological parameters that will help to make due administrative decisions.

Long term experience in studying air pollution have been accumulated, natural experiments on control of impurities dissemination have been carried out, and basic regularities of transfer have been obtained [1]. Accuracy of models intended for calculation of impurities dissemination in atmosphere is the main thing for environment protection activities. Calculation methods for impurities dissemination in atmosphere is basically suitable for the conditions of thermally uniform and smooth relief $[7,8]$.

The relevance of this work is determined by the necessity to model pollution of air basin of industrial centres for complex study of pollutants dynamics in air basin of certain region, by providing the opportunity to carry out computational experiments taking into account the current information, and by studying different situations within the frameworks of the chosen scenario.

\section{Determination of the probability factor of particles movement}

The given article considers determination of the probability factor of particles movement in a gas-dispersed turbulent flow of atmospheric boundary layer for probable - statistical model described in the work [8].

The work [8] considered impurity particles movement as a sequence of step movements that are $h$ long in small periods of time $\Delta t$ in one of four possible directions on the vertical plane.

Movement directions were defined every time by corresponding probabilities $p_{i}: p_{+x}, p_{-x}, p_{+y}, p_{-y}$, and naturally in accordance with normalization requirement that is at any moment of time

$$
p_{+x}(t)+p_{-x}(t)+p_{+y}(t)+p_{-y}(t)=1
$$

Applying approximants for recurrent Poissonian flow of events and law of large numbers, passing to the limit when $\Delta t \rightarrow 0$ and adding the function describing sources of harmful impurities emissions we have got the following equation in the plane $(x, z)$ :

$$
\begin{aligned}
& \frac{\partial \phi}{\partial t}=\mu_{+x, i, j} \\
& \left.+\phi_{i-1, j}^{n}-\phi_{i, j}^{n}\right)+ \\
& +\mu_{-x, i, j}\left(\phi_{i+1, j}^{n}-\phi_{i, j}^{n}\right)+ \\
& \quad+\mu_{+z, i, j}\left(\phi_{i, j-1}^{n}-\phi_{i, j}^{n}\right)+ \\
& \quad+\mu_{-z, i, j}\left(\phi_{i, j+1}^{n}-\phi_{i, j}^{n}\right)+f
\end{aligned}
$$

The equation (2) is identical to difference analogue of transfer equations. Difference analogue of transfer equations in continuous medium can be in the following form taking into account diffusion process and using the scheme accounting the sign:

$$
\begin{aligned}
\frac{\varphi_{i, j}^{n+1}-\varphi_{i, j}^{n}}{\tau}= & {\left[\frac{\mu_{x}}{h_{1}^{2}}+\frac{u+|u|}{2 h_{1}}\right]\left(\varphi_{i-1, j}^{n}-\varphi_{i, j}^{n}\right)+} \\
& +\left[\frac{\mu_{x}}{h_{1}^{2}}+\frac{u-|u|}{2 h_{1}}\right]\left(\varphi_{i+1, j}^{n}-\varphi_{i, j}^{n}\right)+ \\
& +\left[\frac{\mu_{z}}{h_{2}^{2}}+\frac{w+|w|}{2 h_{2}}\right]\left(\varphi_{i, j-1}^{n}-\varphi_{i, j}^{n}\right)+ \\
& +\left[\frac{\mu_{z}}{h_{2}^{2}}+\frac{w-|w|}{2 h_{2}}\right]\left(\varphi_{i, j+1}^{n}-\varphi_{i, j}^{n}\right)+f_{i, j}
\end{aligned}
$$


It is seen to be that transitions intensity $\mu_{+x, i, j}, \mu_{-x, i, j}, \mu_{+z, i, j}$ and $\mu_{-z, i, j}$ are defined as follows

$$
\begin{aligned}
& \mu_{+x}=\frac{\mu_{x}}{h_{1}^{2}}+\frac{u+|u|}{2 h_{1}}, \quad \mu_{-x}=\frac{\mu_{x}}{h_{1}^{2}}-\frac{u-|u|}{2 h_{1}}, \\
& \mu_{+z}=\frac{\mu_{z}}{h_{2}^{2}}+\frac{w+|w|}{2 h_{2}}, \quad \mu_{-z}=\frac{\mu_{z}}{h_{2}^{2}}-\frac{w-|w|}{2 h_{2}}
\end{aligned}
$$

Instantaneous speed of atmosphere at any point of the flow in every direction can be presented as the sum of average speed and pulsation speed:

$$
u=\bar{u}+u^{\prime}, w=\bar{w}+w^{\prime}
$$

where $\bar{u}, \bar{w}$ are components of wind speed, $u^{\prime}, w^{\prime}-$ stochastic process. When there is no wind in atmosphere, intensity of turbulent pulsations can be considered equal in all directions, i.e. $\mu_{x}=\mu_{z}$, so probabilities of movement can also be considered equal, i.e. $u^{\prime}=w^{\prime}$.

When equations (2) were calculated, transitions intensity $\mu_{+x, i, j}, \mu_{-x, i, j}, \mu_{+z, i, j}$ and $\mu_{-z, i, j}$ were defined according to (3) taking into account normalization requirements (1). Such approach provides implementing the terms of mass conservation and enables to define the amount of emitted pollutants into the atmosphere for certain period of time.

During numerical simulations two boundary conditions were taken into account:

first - free boundary

$$
\begin{aligned}
& \left.\frac{\partial \phi}{\partial t}\right|_{x=X}=\mu_{+x, n 1, j}\left(\phi_{n 1-1, j}^{n}-\phi_{n 1, j}^{n}\right)+ \\
& +\mu_{-x, n 1, j}\left(-\phi_{n 1, j}^{n}\right)+ \\
& \quad+\mu_{+z, n !, j}\left(\phi_{n 1, j-1}^{n}-\phi_{n 1, j}^{n}\right)+ \\
& \quad+\mu_{-z, n !, j}\left(\phi_{n 1, j+1}^{n}-\phi_{n 1, j}^{n}\right)+f
\end{aligned}
$$

it means that impurity flows out easily but doesn't flow in. Thus, if it is required, we can define amount of impurities that were brought out from computational region for self-purification with wind regimes and second - solid boundary.

$$
\begin{aligned}
&\left.\frac{\partial \phi}{\partial t}\right|_{z=0}=\mu_{+x, i, 1}\left(\phi_{i-1,1}^{n}-\phi_{i, 1}^{n}\right)+ \\
&+\mu_{-x, i, 1}\left(\phi_{i+1,1}^{n}-\phi_{i, 1}^{n}\right)+ \\
& \quad+\mu_{+z, i, j}\left(-\phi_{i, 1}^{n}\right)+ \\
& \quad+\mu_{-z, i, 1}\left(\phi_{i, 2}^{n}\right)+f
\end{aligned}
$$

in this case the impurity neither flows in nor flows out. In the same way it is possible to get boundary conditions for other boundaries of the considered area.

\section{Results}

The model that was described above with the help of probability-stochastic approaches was used for defining transition intensity. This helped to carry out methodological calculations of point and linear sources.

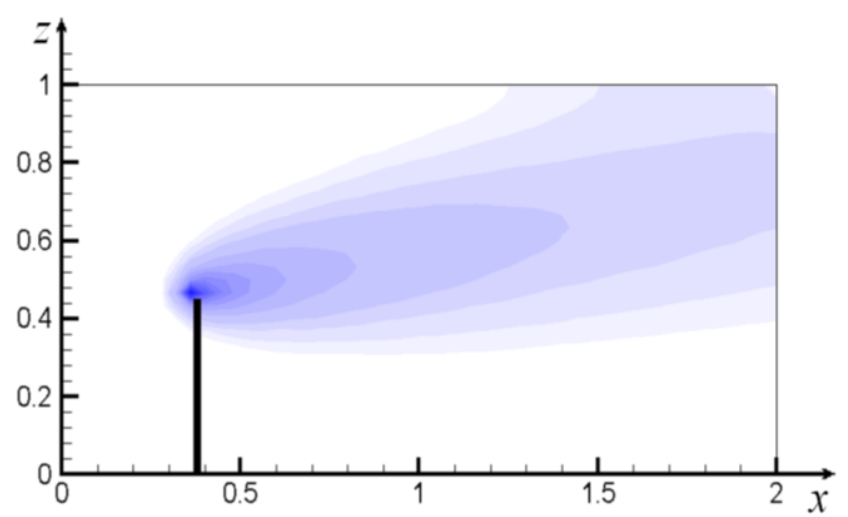

Fig. 1. Wind speed $1 \mathrm{~m} / \mathrm{s}$, point source

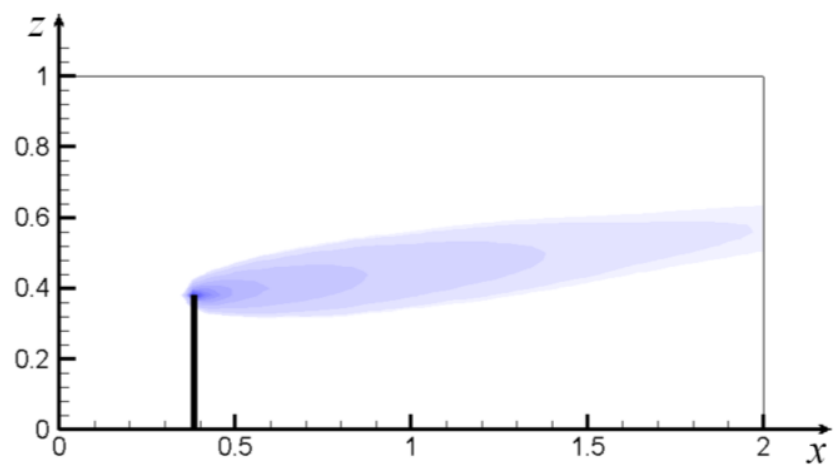

Fig. 2. Wind speed $3 \mathrm{~m} / \mathrm{s}$, point source

When model for dissemination of harmful impurities from stationary sources (Figures 1 and 2) is used, the influence of wind speed regime can be seen well. When wind speed is $1 \mathrm{~m} / \mathrm{s}$ the transfer process goes on more slowly and influence of diffusion processes (Figure 1) is evident. When wind speed is $3 \mathrm{~m} / \mathrm{s}$ impurity is carried away faster, avoiding diffusion processes influence (Figure 2).

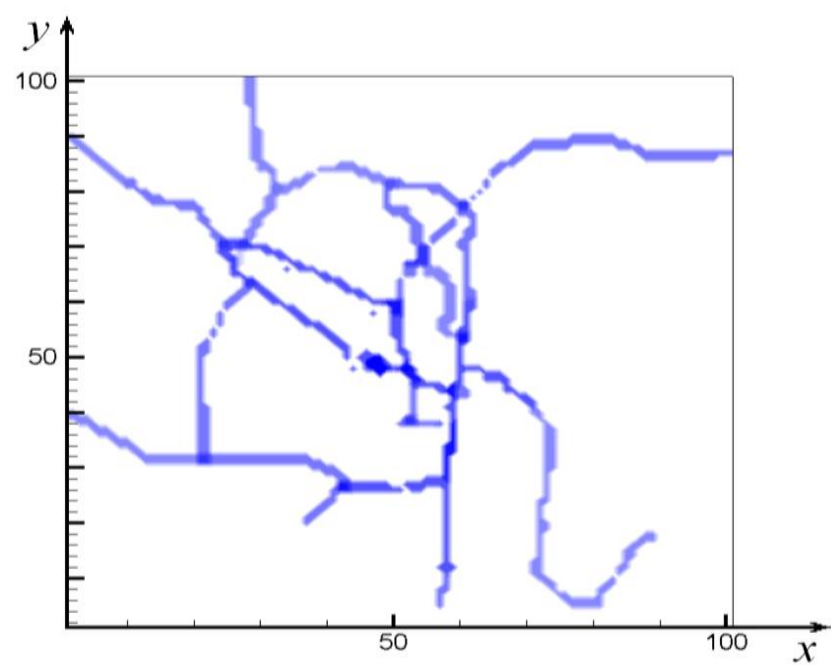

Fig. 3. Input data of linear source 


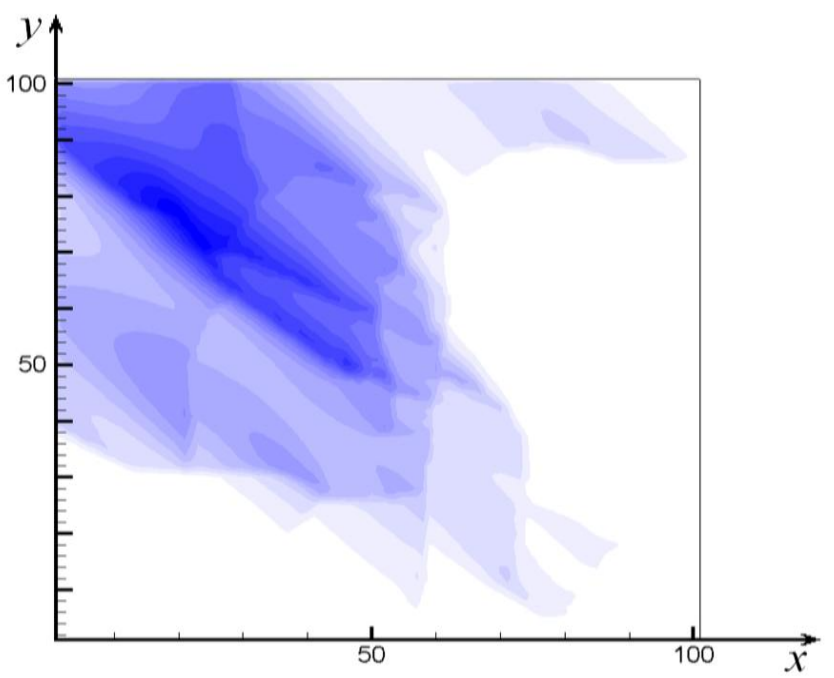

Figures 3 and 4 represent the results of calculations of harmful contaminants transfer from linear sources on horizontal section. Initial values from linear sources represented in figure 3 (road network of cities) were taken from works [6-8], and Figure 4 provides the results of numerical calculation of the task (2), (5), (6), coincide with the result of the work [7, 8].

In order to simulate the process of harmful impurities dissemination from vehicles in atmospheric air, Web-oriented information system was developed on the basis of probabilitystatistical model. The system evaluates the level of pollution from vehicles in surface layer of city atmosphere. The results of emissions dissemination are shown in Figure 5.

Fig. 4. Expansions from linear source, wind speed is $5 \mathrm{~m} / \mathrm{s}$

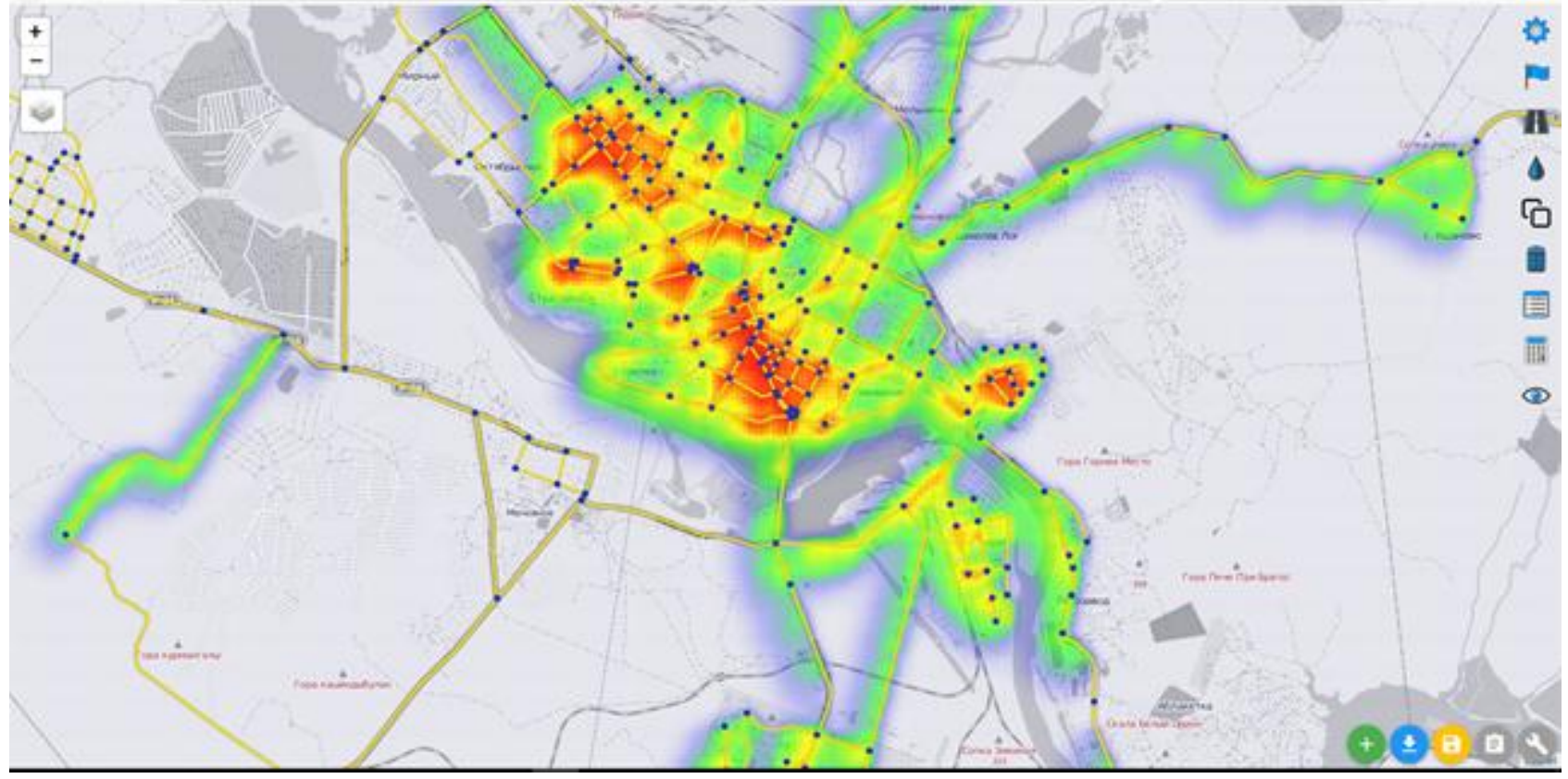

Fig. 5. Dissemination of emissions from vehicles

\section{Conclusion}

There are different methods of mathematical modelling of information systems for ecological monitoring of air basin: empiric-statistical method, method of forecasting increased pollution level, method of Gaussian plume model, dynamicalstochastic method.

The basic method chosen in the work is probability-statistical method. It is used for development of the algorithm of numerical modeling of harmful substances transfer process in atmosphere.

Thus, due to turbulent gas flow, it is characteristic that pulsations of speed in all directions are random and chaotic in all points of atmospheric air flow that makes processes be stochastic [8].

The use of probability-statistical modeling for harmful contaminants transfer in atmosphere enables to build up effective numerical algorithms of calculations and considerably reduces amount of calculations, computing time without loss of accuracy.

Information system is based on the model. The developed computer technology enables to display graphically the level of pollution in surface layer of atmosphere on the map of city territory. It also enables to simulate emissions under different traffic conditions and in different regimes of industrial enterprises operation, and to assess the degree of ecological conflict for every condition. Monitoring results can be used for development of routes, traffic schedules of public transport, and operation modes at industrial enterprises where sanitary standards of pollution are observed.

\section{References}

[1] Antonia R.A., Luxton R.E.: The Response of a Turbulent Boundary Layer to a Step Change in Surface Roughness, Pt. 1. Smooth to Rough. J. Fluid Mech. 48/1971, 721-762.

[2] Betchov R.: Transition, Handbook of Turbulence, Vol. 1. eds. W. Frost \& T. H. Moulden. Plenum Press, New York 1977.

[3] Cao Y., You J., Shi Y., Hu W.: Evaluation of automobile manufacturing enterprise competitiveness from social responsibility perspective. Problemy Ekorozwoju/Problems of Sustainable Development 11(2)/2016, 89-98.

[4] Castillo L.: Similarity analysis of turbulent boundary layers. Ph. D. Thesis, The Graduate School of the State University of New York, Buffalo.

[5] Cel W., Czechowska-Kosacka A., Zhang T.: Mitigation of greenhouse gases emissions. Problemy Ekorozwoju/Problems of Sustainable Development 11(1)/2016, 173-176.

[6] Danaev N.T., Temirbekov A.N., Malgazhdarov E.A.: Modelling of Pollutants in the Atmosphere Based on Photochemical Reactions. Eurasian ChemicoTechnological Journal 16(1)/2014, 61-71.

[7] Temirbekov N., Abdoldina F., Madiyarov M., Malgazhdarov E.: Journal of Computational Technologies, Special Issue 11/2006, 41-45.

[8] Wojcik W., Adikanova S., Malgazhdarov Y.A., Madiyarov M.N., Myrzagaliyeva A.B., Temirbekov N.M., Junisbekov M.: Probabilistic and Statistical Modelling of the Harmful Transport Impurities in the Atmosphere from Motor Vehicles. Rocznik Ochrona Srodowiska 19/2017, 795-808. 


\section{Ph.D. Saltanat Adikanova}

e-mail: ersal_7882@mail.ru

Saltanat Adikanova is a senior lecturer of subdepartment "Computer modeling and information technologies" of S.Amanzholov East Kazakhstan state university.

She defended Doctor's thesis "Development of information system for modeling air pollution by vehicles" in 2018.

Research interests are modeling of complicated processes, development of monitoring information systems.

ORCID ID: 0000-0003-0085-8384

\section{Prof. Waldemar Wójcik}

e-mail: waldemar.wojcik@pollub.pl

Director of Institute of Electronic and Information Technologies, Faculty Electrical Engineering and Computer Science, Lublin University of Technology. His research interests include electronics, automatics, advanced control techniques, the optimization of the industrial processes, and fiber optic sensors including fiber Bragg gratings.

ORCID ID: 000-0002-0843-8053

\section{Ph.D. Natalya Denissova}

e-mail: nata69_07@mail.ru

Natalya Denissova, takes position of vice-rector on informatization, and director of Information Technology Department at D.Serikbaev East Kazakhstan state technical university.

She graduated I.Polzunov Altai state technical university and defended Candidate's dissertation "Computer modeling of thermo-activated structural change in biocrystal Ni-Al" in 2006.

Scientific interests: modeling information processes and systems, new communication technologies.

ORCID ID: 0000-0005-0525-730X

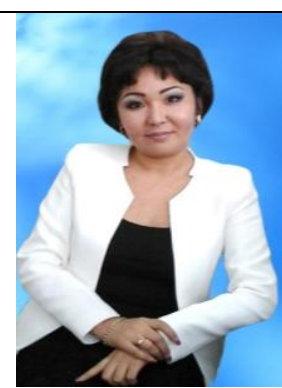

Ph.D. Yerzhan Malgazhdarov

e-mail: malgazhdarov_e@mail.ru

Ye. Malgazhdarov is Head of sub-department "Instrument engineering and automation of technological processes" at D.Serikbaev East Kazakhstan state technical university.

Ye. Malgazhdarov defended successfully his Candidate's dissertation on January 29, 2010 on specialty 05.13.18 - „Mathematical modeling, numerical methods, and software systems".

Scientific interests: modeling of complicated processes, new communication technologies. ORCID ID: 0000-0003-4218-3469

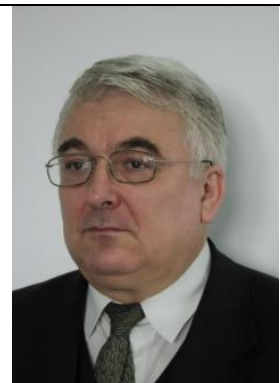

Ph.D. Ainagul Kadyrova

e-mail:k_ainagul07@mail.ru

Ainagul Kadyrova works at sub department "Computer modeling and information technologies" of S.Amanzholov East Kazakhstan state university.

She defended Candidate's thesis successfully in 2010

Research interests are high school pedagogics, teaching mathematical modeling, artificial intelligence, natural language processing.

ORCID ID: 0000-0001-6897-9380

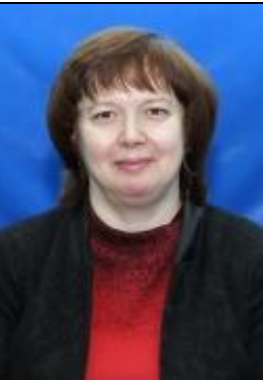

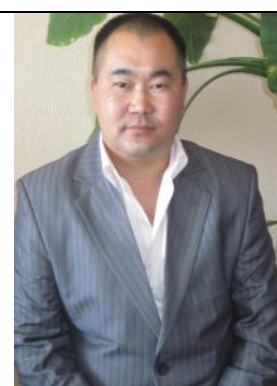

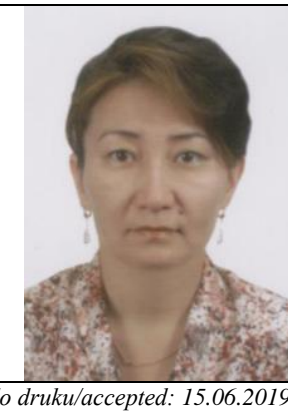

